larger professional contribution in posts appropriate to their capabilities, and have a chance to influence departmental and hospital policies. At a time when specialist training is becoming more prolonged we see the increase in posts of senior house officer grade as giving us registrars by another name, and pushing the bottle-neck further down the career ladder.

If both foreign and British graduates are to be doing the same rotations, and if the posts are to be of equal quality, then the contracts must all be held at regional headquarters so that acceptable rotations can be organised. As a majority of registrars will eventually obtain consultant appointments in district general hospitals, we believe that it should be obligatory for all registrars to have at least two years' experience in such hospitals. Opportunities for overseas graduates to work in teaching hospitals should also be available.

Despite much time and thought having been given to the problem of hospital staffing in 1980-81, little progress had been made by 1985 . What has happened since then that could not have been foreseen? We now have imposed on us an ill thought out, hasty, and short sighted solution in a struggling hospital service, which remains unsympathetic to the requirements of flexibility that are now needed for $50 \%$ of medical school graduates, so that their full potential may be realised.

H P McDowell and J GREGG Royal Liverpool Children's Hospital, Alder Hey, Liverpool L12 2 AP

\section{Concern over safety of SAGM blood}

Sir,

We read with interest the letter from Drs Roberton and Chiswick. We recently carried out an exchange transfusion in a neonate using $500 \mathrm{ml}$ of partially packed SAGM blood. She was born at 38 weeks' gestation, weighed $3000 \mathrm{~g}$ at birth, and required an exchange transfusion for $\mathrm{ABO}$ group incompatibility when 19 hours old.

Before the transfusion the infant's total serum protein concentration was $58 \mathrm{~g} / \mathrm{l}$, and the serum albumin concentration was $36 \mathrm{~g} / \mathrm{l}$. These fell to $43 \mathrm{~g} / \mathrm{l}$ and $28 \mathrm{~g} / \mathrm{l}$, respectively, immediately after the transfusion. By the following day the patient's total serum protein concentration was $52 \mathrm{~g} / \mathrm{l}$ with a serum albumin concentration of 32 $\mathrm{g} / \mathrm{l}$. A coagulation screen immediately after the transfusion showed a prothrombin ratio of $1: 3$, a kaolin cephalin coagulation time of 39 seconds [control 38 seconds], and a prothrombin time of 22 seconds [control 19 seconds].

This infant tolerated a SAGM exchange transfusion with a temporary fall in plasma protein concentration and no disturbance of coagulation. Partially packed SAGM contains protein concentrations that are one third to one half of those of normal plasma. Though SAGM donor blood may be safe for use in exchange transfusions in the well term infant, further assessment is required in the ill low birthweight baby. Reference
1 Roberton NRC, Chiswick ML. Concern over safety of SAGM
blood. Arch Dis Child 1987;62:638.

S W RYAN

Clarendon Wing,

Leeds General Infirmary,

Leeds

B BHADURI

York District Hospital,

York

M J HARRAN

York District Hospital,

York

\section{Peptic ulceration: long term outcome}

Sir,

Murphy et al reviewed 110 children with duodenal ulcers. ${ }^{1}$

We are carrying out a long term follow up study of 36 children with peptic ulcers. The clinical features are similar but the long term outcome is different. The aim of our study, begun in 1982, was to determine endoscopically the healing rate after eight weeks of treatment with ranitidine, and the rate of relapse after stopping the drug. Endoscopy was repeated every six months or when symptoms recurred. For ethical reasons no placebo group was included.

The average number diagnosed annually was seven, the mean age at diagnosis was 9 years 7 months (range 18 months to 19 years), the male:female ratio was $1 \cdot 8: 1$ and the mean duration of symptoms before diagnosis two years four months. There was a family history of peptic ulcer in $47 \%$. The commonest symptoms were abdominal pain $(91 \%)$, vomiting $(47 \%)$, and bleeding $(11 \%)$. The maximal acid output after pentagastrin stimulation was two standard deviations above normal in $66 \%$. Of six patients with antral and prepyloric ulcers the maximal acid output was raised in five and normal in one, suggesting an identical pathogenetic factor. ${ }^{2}$

The table shows the sites of the ulcers, the rate of healing in 34 patients, and the rate of relapse in the 30 who were followed for more than a year. Though our series is smaller than that reported by Murphy et al, some of these preliminary data can be compared with his.

The main difference is in the rate of relapse $(36 \%$ compared with $70 \%$ ) and the length of time before relapse

Table Features of peptic ulcers in 36 patients

\begin{tabular}{lccc}
\hline Features of ulcers & $\begin{array}{l}\text { No of } \\
\text { boys } \\
(n=23)\end{array}$ & $\begin{array}{l}\text { No of } \\
\text { girls } \\
(n=13)\end{array}$ & $\begin{array}{l}\text { Total } \\
\text { No } \\
(n=36)\end{array}$ \\
\hline Site: & 18 & 10 & 28 \\
$\quad$ Duodenum & 5 & 3 & 8 \\
$\quad$ Antrum or prepyloric zone & $22 / 23$ & $10 / 11$ & $32 / 34$ \\
No healed after eight weeks & $9 / 21$ & $2 / 9$ & $11 / 30$ \\
No relapsed & & & \\
\hline
\end{tabular}


(mean 17 months, range four months to three years, and only two who relapsed within the first year). We adopted different criteria from Murphy et al to assess the rate of relapse: in their study recurrence of symptoms was considered to be a relapse. In five of our patients symptoms recurred but endoscopy failed to show any ulcer and none had symptoms of relapse at endoscopy. No differences were found between those who relapsed and those who did not in family history, duration of symptoms, or gastric acidity.

\section{References}

1 Murphy MS, Eastham EJ, Jimenez M, Nelson R, Jackson RH. Duodenal ulceration: a review of 110 cases. Arch Dis Child 1987;62:554-8.

2 Tatsuda M, Iishi H, Okada S. Effects of cimetidine on the healing and recurrence of duodenal ulcers and gastric ulcers. Gut 1986;27:1213-8.

G Oderda, Laura Farina, and Nicoletta Ansaldi Servizio di Gastroenterologia, Cattedra di Puericultura, Universita di Torino, 10125 Torino, Italy

\section{Enuresis in children}

\section{Sir,}

I was interested to read your correspondent's personal view of her enuresis and her observations on its management. ${ }^{1}$ One can't but help sympathise with her. In my experience most parents of enuretic children are bothered not so much by the nuisance that it causes them but by whether it could be a symptom or sign of disease in soma or psyche; if they are reassured on that score they can usually cope until the child demands to be 'cured'. As we all know, wetting can be a manifestation of many diseases: of the urinary tract, of the upper respiratory tract (obstruction at night), of the endocrine system (diabetes mellitus, diabetes insipidus, and Addison's Disease), of the gut (coeliac disease with intestinal water retention), of the cardiovascular system (improving renal perfusion at rest), of the hypothalamus (failure of development of diurnal rhythms), of the central nervous system (nocturnal or early morning fits), or of the psyche; these should be carefully excluded before the symptom is 'treated' on its own merits. For this reason, and because it represents a stigma, attendance at so called enuretic clinics may be harmful, as is the provision of a star chart-implying that the wetting is under voluntary control-or the imposition of an alarm (although this can be very helpful when managed by the child himself). Drugs like imipramine do seem to help but they bring 'magic' into the management, are dangerous in overdose, and do not have a convincing rationale in relation to bladder innervation, if indeed they do act by increasing capacity. In this context it is interesting that nearly all nocturnal enuretics are wet before their parents go to bed.

Perhaps as members of a profession whose practice is supposed to be science based we should confine ourselves to sorting out and acting on what we do know of the pathogenesis and leave the rest to growing up, practical sympathy, education for all concerned-particularly teachers-and common sense measures to mitigate nuisance like the provision of a washing machine, using a covered mattress and easy to wash sheets (supplemented by newspapers used as blotting paper), and a potty under the bed.

\section{Reference}

${ }^{1}$ Anonymous. My enuresis. Arch Dis Child 1987;62:866-8.

$$
\begin{array}{r}
\text { J A Davis } \\
\text { Department of Paediatrics, } \\
\text { University of Cambridge Clinical School, } \\
\text { Level 8, Addenbrooke's Hospital, } \\
\text { Hills Road, Cambridge } \\
C B 22 Q Q
\end{array}
$$

\section{Hearing loss due to mumps}

Sir,

We share the opinion of Hall and Richards that mumps is a major cause of severe sensorineural hearing loss. ${ }^{1}$ During an epidemic of mumps in Israel in 1984, 85 children with mumps were admitted to the paediatric department of the Beilinson Medical Center, which serves an area of roughly 68000 children (age 0-14 years). Seventy nine of the patients had symptoms or signs of meningoencephalitis. Three children $(3.5 \%)$ developed unilateral profound sensorineural deafness in association with mumps.

The first was a 3 year old boy who had bilateral parotitis and meningeal irritation. Cerebrospinal fluid examination showed 1020 cells $/ \mathrm{mm}^{3}$ (98\% mononuclear cells), and mumps virus was subsequently isolated from this fluid. During his stay in hospital his parents noticed that he did not respond to calls, and audiometry showed right severe sensorineural hearing loss.

The second patient was a 10 year old girl with bilateral parotitis, severe headache, and vomiting. On the sixth day in hospital she complained of inability to hear a telephone conversation through her right ear, and severe sensorineural hearing loss was documented by audiometry.

The third patient was a 8 year old girl who was admitted for observation with fever of $39^{\circ} \mathrm{C}$. In the ward she complained of inability to hear with the right ear, and this was confirmed by audiometry. As we were aware of the association of hearing loss and mumps this possibility was tested, and her complement fixation antibody for mumps rose from $1 / 20$ to $1 / 240$ within three weeks, which confirmed recent infection. Routine hearing screening tests done on these three patients before the disease gave normal results. All the other children with mumps who were in hospital were tested and no significant hearing abnormalities were found.

A postal inquiry, albeit with an incomplete response, showed three additional cases of deafness after mumps in 1984 , one of them with severe bilateral hearing loss. 